
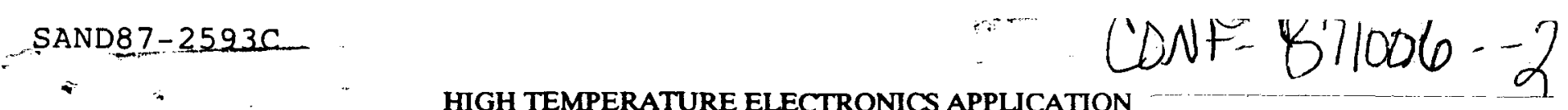

\author{
R. K. Traeger \\ P. C. Lysne \\ Department 6240 \\ Sandia National Laboratories \\ P. O. Box 5800 \\ Albuquerque, New Mexico
}

SAND--87-2593C

DE88 001677
Commercial systems used in well logging are available for routine use at temperatures to $160^{\circ} \mathrm{C}$ and other hostile environment systems have advertised capabilities to $260^{\circ} \mathrm{C}$. However, scientific wells, deep gas wells, geothermal wells and boreholes used for the diagnostics of in situ processes such as fire and steam floods can have borehole temperatures up to $500^{\circ} \mathrm{C}$ which eliminate the use of existing logging tools or borehole diagnostic systems.

In the late 1970's and early 1980's a significant effort was mounted by the DOE/Geothermal Technology Division to develop and commercialize high temperature logging systems. Results of this effort are summarized in the proceedings of several meetings $(1,2,3)$ and a Source book. $(4)$ In the early 1980's, prototype components were available that could be used in logging tools for use at $250-300^{\circ} \mathrm{C}$. However, in the 1980's the need for such high temperature systems was insufficient for suppliers to routinely provide these components.

Looking ahead at future high temperature logging applications, we recognize that electronics are only one part of a logging system, and all aspects and hardware must be compatible with high temperature use. Therefore, an overall system design must consider: components,

1. the market needed to assure supply of specialty

2. measurement needs in terms of time, temperature and environment;

3. the effect of temperature on the formation being interrogated; and

4. that electronics, interconnections, cables, cable heads, sensors and housings are all system components which individually or interconnected may be the source of the temperature limit.

Some of these items will be reviewed in the following paper in terms of tools used for neutron logging.

\section{Measurement Needs}

Logging measurement needs can be split into two areas, i.e., reservoir evaluation logging and production logging. The reservoir evaluation logs are run as fast as possible whereas production logging may require that tools stay in the wellbore for much longer periods of time. The neutron tools are for reservoir studies and have round-trip times on the order of 10 hours. As long as temperatures are below the cable degradation levels, high temperature problems on the tool itself can be mitigated by the use of dewars and heat sinks, a common practice in the industry. This will be discussed later for neutron tools.

\section{Logging System}

Common logging systems consists of:

1. the wellbore and its environment;
2. surface instrumentation to provide diagnostic signals, and to record and analyze the data;

3. a logging cable that transmits power and data; tool; and

4. a cable head that ties the cable to the logging

5. the logging tool which in turn consists of the mechanical housing, the sensor, and the electronics.

Wellbore and Environment: The logging tool measures a response of a perturbation in the formation, i.e., a change in the thermal neutron absorption. The design of any tool must include consideration of change to the signal (i.e., neutron scattering) due to the changing environment (i.e., temperature). Some of these calibration considerations are discussed in Section V.

Surface Instrumentation: High borehole temperatures do not effect the surface hardware but may be important in the software analysis of the data.

Logging Cable: Logging cables are a weak link in logging systems operating to $300^{\circ} \mathrm{C}$. Multi-conductor cables using tefion TFE are stated for use to $320^{\circ} \mathrm{C}$. However, electrical failures above $300^{\circ} \mathrm{C}$ are common. Furthermore, mechanical failures of the armor are often related to the corrosive environment of a hot borehole.

Steel sheathed, $\mathrm{MgO}$ insulated cables are available for use to $600-800^{\circ} \mathrm{C}$. The high capacitance of the $\mathrm{MgO}$ leads to high power loss and low bandwidth and the small size of the conductors limits power transmission. Field-compatible cable heads and take up systems are not standard, and problems caused by work hardening the sheath during reeling have not been addressed.

A possible future solution is the use of metal sheathed, fiber optics. Chevron (5) has recently tested optic logging cables at low temperature and metal sheathed fiber optics have been tested to $400^{\circ} \mathrm{C}$. Many technical problems need to be solved before considering optics systems for high temperature use but this is obviously a trend for future logging.

Cable Head: The cable-to-tool connection made in the field continually presents the major reliability problem in high temperature logging. Cable heads often rely on elastomer seals and elastomers are unstable above $250-300^{\circ} \mathrm{C}$. Other concepts, as metal-to-metal seals, are possible at higher temperatures but present many field assembly problems.

Logging Tool: The structural case of the tool can be made of high temperature, corrosion-resistant materials, and usually does not limit the design.

Transducers and Sensors: Transducer and sensor limitations obviously depend on the measurements being made and if the sensor can be protected in the housing. In neutron tools, the generators and the sensors can be located in the housing as long as that housing has no high cross section elements. 


\section{DISCLAIMER}

This report was prepared as an account of work sponsored by an agency of the United States Government. Neither the United States Government nor any agency Thereof, nor any of their employees, makes any warranty, express or implied, or assumes any legal liability or responsibility for the accuracy, completeness, or usefulness of any information, apparatus, product, or process disclosed, or represents that its use would not infringe privately owned rights. Reference herein to any specific commercial product, process, or service by trade name, trademark, manufacturer, or otherwise does not necessarily constitute or imply its endorsement, recommendation, or favoring by the United States Government or any agency thereof. The views and opinions of authors expressed herein do not necessarily state or reflect those of the United States Government or any agency thereof. 


\section{DISCLAIMER}

Portions of this document may be illegible in electronic image products. Images are produced from the best available original document. 
below.

Electronics: Electronics limitations are discussed

\section{High Temperature Electronic}

Active and passive devices plus interconnections are the three components of an electronic system. Fundamental limitations automatically put a temperature cap of $300-350^{\circ} \mathrm{C}$ for organic materials (insulators, coatings, elastomers, adhesives, etc.) and $250^{\circ} \mathrm{C}$ for silicon devices. $(6,7)$ Consequently, most commercially available components limit systems to below $275-325^{\circ} \mathrm{C}$.

Interconnections: The most commercially and technically available high temperature interconnection systems use hybrid, thick film technology for putting conductors, bonding pads, etc., on alumina substrates. Production of thick film systems require firing at $800-1000^{\circ} \mathrm{C}$ and consequently the circuits are inherently stable. Wire or ribbon connections can be made by welding or brazing to provide stability at high temperature. A thick film circuit operating at $400^{\circ} \mathrm{C}$ was recently proposed as a gas sensor.(8)

If maximum temperatures are limited to the 250$300^{\circ} \mathrm{C}$ range, polyimide-glass printed wiring boards can be used with high temperature solders or brazes.

Passive Devices: Discreet capacitors, resistors, and inductors almost always include organies and low melting point materials for ease of assembly. However, proper design and material selection can provide components usable at 250$275^{\circ} \mathrm{C}$. Some of the problems and solutions are mentioned for these components in the Source book.(4)

The thick film technology can also provide screen printed, high temperature resistors and capacitors.

Active Devices: Semiconductor components currently limit the high temperature potential of electronic systems. Although junction isolation can be built into devices, leakage and recombination rates increase rapidly with temperatures. Silicon devices generally fail above $250-275^{\circ} \mathrm{C}$ because of leakage. Zipperian(6,7) recently reviewed the temperature limitations of active devices and indicated that experimental GaP devices have functioned satisfactorily at $550^{\circ} \mathrm{C}$.

Active thermionic devices, that use principles of vacuum tubes, have been built that operate at $500-600^{\circ} \mathrm{C}$.(9) These require a power supply to maintain that temperature and a mechanism to remove the heat. In general, the thermionics are difficult to use with other components in high temperature environments.

\section{Dewared Systems}

In considering technical and commercial aspects of building high temperature logging tools, we are limited to 275 $300^{\circ} \mathrm{C}$ operation by the cable/cable head problem. For lithologic logging, the best system appears to be the TFE logging cable connected to a dewared logging tool. Thus, commercially available components can be used. The length of time at temperature then depends on the insulating capabilities of the dewar, the heat sink on board the tool, and the most temperature sensitive electronic component.

Efficient head sinks can be made by utilizing the latent heat of the solid-liquid transition of an appropriate alloy. A eutectic alloy of $55 \% \mathrm{Bi}$ and $45 \% \mathrm{~Pb}$ is attractive for neutron tools due to its low thermal neutron absorption cross section. Its melting temperature is $125^{\circ} \mathrm{C}$ and the enthalpy charge of this transition is $712 \mathrm{cal} / \mathrm{mole}$.

The limitation of the cable can be removed by using a self-contained downhole tool with power, data processing and storage, and timers. The tool would be lowered on a structural, nonelectrical cable. This concept was used to measure temperature and pressure in a geothermal well over $300^{\circ} \mathrm{C}$; the tool was designed to operate for ten hours at $400 \cdot \mathrm{C} .(8)$

\section{Calibration Considerations}

Environmental Effects: One difficulty is presented by the thermal dependence of the scattering and absorption properties of rock and fluid materials. In regard to fluids, one must take into account the decrease in density caused by expansion effects. Such a correction requires a knowledge of the borehole temperature.

Another problem is that the energy of a "thermal" neutron at $300^{\circ} \mathrm{C}$ is about twice that of a thermal neutron at $1^{\circ} \mathrm{C}$ For many crustal elements, i.e., $\mathrm{O}, \mathrm{Ca}, \mathrm{Mg}, \mathrm{Si}, \mathrm{C}$, etc., the absorption cross section decreases as energy-1/2. If all elements behaved in this manner, the corrections would be straightforward. However, some trace elements with very large microscopic cross sections do not possess an energy- $/ / 2$ behavior and they may preclude a simple interpretation of log data.

Temperature effects such as those discussed above are difficult to explore experimentally. Computer simulation codes are available which can be used to evaluate the calibration problem.

\section{References}

[1] Veneruso A. F., R. S. Simpson and C. Arnold (Editors), "High Temperature Electronics and Instrumentation Seminar Proceedings, December 3-4, 1979," SAND80-0834C, Sandia National Laboratories, Albuquerque, NM, 258 pp., May 1980.

[2] Hudson, S. R. and J. R. Kelsey (Editors), "Proceedings-High Temperature Electronics and Instrumentation Conference, December 1981," SAND82-0425, Sandia National Laboratories, Albuquerque, NM 201 pp., February 1982.

[3] Dennis, B. R. (Editor), "Symposium on HighTemperature Well Logging Instrumentation, Nov. 13-14, 1985," LA-10745-C, Los Alamos National Laboratory, Los Alamos, NM, 117 pp., June 1986.

[4] Veneruso, A. F., "Sourcebook on HighTemperature Electronics and Instrumentation," SAND81-2212, Sandia National Laboratories, Albuquerque, NM, 174 pp., October 1981.

[5] Angehrn, J. A., and S. A. Sie, "A High Data Rate Fiber Optic Well Logging Cable," The Log Analyst, March-April, 1987.

[6] Zipperian, T. E., "A Survey of Materials and Device Technologies for High-Temperature $\left(\mathrm{T}>300^{\circ} \mathrm{C}\right)$ Power Semiconductor Electronics.

[7] Zipperian, T. E., T. M. Brennan and B. E. Hammons, "Compound semiconductor Heterojunction Device Technologies for High-Temperature $\left(\mathrm{T}>300^{\circ} \mathrm{C}\right)$ Power Electronics," 22nd Intersociety Energy Conversion Engineering Conference, Philadelphia, August 1987. 
[8]" Kaneyasu, M., et al, "Smell Identification Using Thick-Film Hybrid Gas Sensor," IEEE Trans. on Components, Hybrids and Manufacturing Technology, V. CHMT-10, No. 2. pp. 267-273, June 1987.

[9] Yee, J. H., et al, "High Temperature, Radiation-Tolerant Electronics for the MMW Space Power Reactor Program," LLNLUC ID 20892, 16 pp., Oct. 17, 1986.

[10] Carson, C. C., "Development of Downhole Instruments for Use in the Salton Sea Scientific Drilling Project," Transactions of the Geothermal Resources Council, V. 10, 449-453, Sept. 1986.

\section{DISCLAIMER}

This repori was prepared as an account of work sponsored by an agency of the United States Government. Neither the United States Government nor any agency thereof, nor any of their employees, makes any warranty, express or implied, or assumes any legal liability or responsibility for the accuracy, completeness, or usefulness of any information, apparatus, product, or process disclosed, or represents that its use would not infringe privately owned rights. Reference herein to any specific commercial product, process, or service by trade name, trademark, manufacturer, or otherwise does not necessarily constitute or imply its endorsement, recommendation, or favoring by the United States Government or any agency thereof. The views and opinions of authors expressed herein do not necessarily state or reflect those of the United States Government or any agency thereof. 